\title{
Physicochemical and Functional Properties of Dioscorea alata L. cv "Brazo" Starch during post-harvest Storage
}

\author{
Souleymane SORH ${ }^{1}$, Michel Archange LIBRA ${ }^{2 *}$, N'Nan Affoué Sylvie DIBY ${ }^{2}$, Soumaïla DABONNE ${ }^{1}$, \\ Lucien Patrice KOUAME \\ ${ }^{1}$ Laboratory of Biocatalysis and Bioprocessing, UFR of Science and Food Technologies, \\ University Nangui Abrogoua Abidjan, PO Box 02 BP 801 Abidjan Côte d'Ivoire \\ ${ }^{2}$ Department of Biochemistry-Genetics, UFR of Biological Sciences, Peleforo Gon Coulibaly University \\ of Korhogo, PO Box 1328 Korhogo
}

Côte d'Ivoire

\begin{abstract}
This study was conducted in order to assess the changes in physicochemical and functional properties of starch of Dioscorea alata L. cv "Brazo" during the post-harvest storage. Tubers were obtained from the experimental farm of University Nangui Abrogoua (Abidjan, Côte d'Ivoire) in West Africa. The results showed that the physicochemical properties of starches such as lipids, proteins and ash did not vary while amylose and amylopectin decreased during the storage time. However, the functional properties did not change significantly during the seven months of storage time. Starches showed a high degree of swelling and solubility and less syneresis when subjected to refrigeration or freezing. The viscoamylogram diagrams of the starch pastes did not give a viscosity peak, but had viscosities that increased during the heating and cooling cycle, suggesting thermo-stability and high retrogradation tendency during cooling. The pasting temperature was high and ranged between 72 and $77^{\circ} \mathrm{C}$. The pasting and cooking time were 20 and 30 min respectively.
\end{abstract}

Keywords: Starch, Dioscorea alata, cultivar Brazo, Functional properties, Post-harvest.

\section{INTRODUCTION}

Yams belong to the family Dioscoreaceae, the genus Dioscorea and the subclass Liliidae. Today, 600 species of yam have been found and distributed throughout the world $[1,2]$. They are widely grown in tropical and subtropical regions of the world. Yams produce starchy edible tubers. Concerning the world production of yams, West Africa occupies the first place [3], representing 93\% of the world production [3, 4]. The genus Dioscorea contains a wide range of yam species used as food. The most economically important grown species are D. cayenensis, D. rotundata, D alata, D. bulbifera, D. esculenta, and D. dumentorum [5]. Named also water yam, Dioscorea alata accounts for between 55\% and 60\% of the yams grown in Côte d'Ivoire and are also grown both in the savanna and in forest regions [6]. Côte d'Ivoire has an annual yam production of about 5.8 million tons [7]. However this amount of yam is far from being sufficient for the population of Côte d'Ivoire whose annual consumption is estimated at $350 \mathrm{~kg}$ par resident [7]. Sub-species of Dioscorea alata, mainly Florido, Brazo fuerte are also grown in Côte d'Ivoire. Dioscorea alata cv. "Brazo" produces starchy tubers and constitutes an important source of carbohydrates for many people in Côte d'Ivoire [6]. These yams have not been processed to any significant extent commercially, but have been limited to the preparation of local dishes such as pounded yam (yam dough), and akpessi (boiled yam). As with other tubers, there are considerable variations in the chemical composition of yams, not only between different species, but also within a single species. This is due to cultural and climatic factors under which yam is cultivated, its maturity stage at harvest and the method and duration of storage [8]. Dioscorea alata cv "Brazo" belongs to the semi-perishable class of food due to its relatively high moisture content. In absence of good storage facilities, yam tubers are prone to gradual physiological deterioration after harvesting. Some previous studies have elucidated the properties of some underutilized yam varieties [9, 10]. However, the functional and rheological properties of $D$. alata cv "Brazo" still remain unknown. In order to reduce postharvest losses of food crops, and 
expand the utilization of this yam, and consequently enhance food security in the ivorian rural area, the present study was conducted to assess the functional and rheological behavior of starch of D. alata cv "Brazo" during the post-harvest period.

\section{MATERIALS AND METHODS}

\subsection{Plant Material}

Mature tubers of Dioscorea alata cultivar "Brazo" were collected from the experimental farm of the University Nangui Abrogoua (Abidjan, Côte d'Ivoire). After harvest, yam tubers were immediately carried to the laboratory and stored under prevailing tropical ambient conditions $\left(31.25 \pm 3.00^{\circ} \mathrm{C}, 81.44 \pm 12.25 \% \mathrm{RH}\right)$ for a period of 7 months.

\subsection{Starch Extraction}

Starch extraction was carried out according to the method described by Archange et al. [11]. Fresh tubers of Dioscorea alata cv "Brazo" were washed, peeled, sliced and steeped in $0.1 \%$ sodium bisulphite solution to prevent browning. The slices were ground in a Moulinex 2000 blender (France) and the paste recovered in 4\% sodium chloride solution, and then sieved successively through $500 \mu \mathrm{m}, 250 \mu \mathrm{m}$ and $100 \mu \mathrm{m}$ sieves. The filtrate was allowed to settle about one hour for decantation. Operations of "settling/decantation" were repeated until the supernatant became clear. Sediment starch was rinsed with $70 \%$ ethanol and the deposit obtained was spread on an aluminium foil paper and oven dried at $47^{\circ} \mathrm{C}$ for 48 hours. The dried starch was ground into powder in a blender (Moulinex 2000) and passed through a $250 \mu \mathrm{m}$ sieve, sealed, and stored for analysis.

\subsection{Determination of Chemical Composition of Starch}

Lipid content was determined by soxhlet extraction with hexane [12]. Ash was determined by measurement of residues left after combustion in a furnace at $550{ }^{\circ} \mathrm{C}$ for 8 hours [12]. Crude protein by determination of nitrogen using a factor of 6.25 . Amylose and amylopectin content were determined following the B.I.P.E.A method [13].

\subsection{Swelling Power}

Starch dispersions $(1 \%)$ were prepared in falcon tubes and heated in a water bath at $60,70,80$, and $90^{\circ} \mathrm{C}$ for 30 min with constant agitation to avoid sedimentation. The heated suspensions were centrifuged at $1,000 \mathrm{~g}$ (Sorvall) for $15 \mathrm{~min}$ at $20^{\circ} \mathrm{C}$. The sediment was weighed and its mass related to the mass of dry starch was expressed as swelling power (w/w) [11].

\subsection{Determination of Pasting Characteristics}

Pasting characteristics of yam starch were determined with a Brabender visco analyzer. Four hundred and fifty (450) $\mathrm{mL}$ of starch slurry $(6 \% \mathrm{w} / \mathrm{w})$ was added to the BRABENDER viscoamylograph. The suspension was heated from $25^{\circ} \mathrm{C}$ to $95^{\circ} \mathrm{C}$ at a rate of $1.5^{\circ} \mathrm{C} / \mathrm{min}$. The temperature was maintained at $95^{\circ} \mathrm{C}$, for $15 \mathrm{~min}$ before cooling to $50^{\circ} \mathrm{C}$ at the same rate. Corresponding values for peak viscosity, holding strength, breakdown, final viscosity, setback, pasting time, pasting temperature and cooking time from the pasting profile were determined.

\subsection{Syneresis of Cooked Starch after Refrigeration and Freeze-Thaw}

Syneresis of starch gels of native starch of $D$. alata cv. "Brazo" during cold and frozen storage was determined according to the methods described by Pingault [14]. A starch suspension ( $8 \%$ dry basis, w/w) was prepared with $0.1 \%$ sodium benzoate to prevent microbial spoilage during repeated refrigeration and freeze-thaw treatments. The suspension was adjusted to $\mathrm{pH} 6.5 \mathrm{with}$ $0.01 \mathrm{M} \mathrm{NaOH}$ or $\mathrm{HCl}$ solutions and heated at $100^{\circ} \mathrm{C}$ for $30 \mathrm{~min}$. After cooling to ambient temperature, $10 \mathrm{~g}$ of the paste were transferred into polypropylene tubes and capped. Starch pastes were stored at $4^{\circ} \mathrm{C}$ for 4 weeks and then held at ambient temperature for $6 \mathrm{~h}$ and centrifuged at $3000 \times \mathrm{g}$ for $10 \mathrm{~min}$. The supernatant was decanted, weighed, and calculated as a percentage from the original weight. This refrigeration cycle was repeated four times for all samples.

Also, starch pastes were stored in a freezer $\left(-18^{\circ} \mathrm{C}\right)$ for 4 weeks and then thawed at $40^{\circ} \mathrm{C}$ for $2 \mathrm{~h}$ to determine the freezethaw stability. The thawed samples were centrifuged at $3000 \times \mathrm{g}$ for $10 \mathrm{~min}$ and the residue was weighed after discarding the supernatant. The gels were refrozen following the measurement of expelled water to repeat the cycle. All starch samples were subjected to four freeze-thaw cycles. Cumulative values for expelled water were obtained after calculating each percentage of expelled water from the remaining gel. Total syneresis was calculated by the addition of mean values of the expelled water from the triplicated samples, after each refrigeration or freeze-thaw treatment.

\subsection{Statisctical Analysis}

All experiments were done in triplicates. Data were subjected to analysis of variance $(\mathrm{P}<0.05)$, and appropriate means separation was conducted by Duncan's multiple range test using Statistica 7.0 software (Statsoft Inc., Tulsa-USA Headquarters). 
International Journal of Advances in Scientific Research and Engineering (ijasre), Vol 5 (8), August-2019

\section{RESULTS AND DISCUSSION}

\subsection{Chemical Composition}

The chemical composition of the isolated starches of Dioscorea alata cv. "brazo" tubers at different period of the postharvest storage is shown in Table 1. Lipids, Proteins and Ash levels were statistically unchanged $(p<0.05)$ during the storage time. Ash values were $0.58 \pm 0.04 \%$ at harvest and $0.54 \pm 0.03 \%$ at 7 th month of storage of time. These values are higher than those reported by an author [15] for starches of some cultivars of cassava: Manihot esculenta $(0.20 \pm 0.04)$ and C. esculanta (0.12 \pm 0.02 ). Lipids and proteins content values were ranging from $0.45 \pm 0.01 \%$ to $0.42 \pm 0.03 \%$ and from $0.97 \pm 0.02 \%$ to $0.81 \pm$ $0.05 \%$ respectively. According to the literature [16], starch may contain minute quantities of lipids, proteins and ash. Amylose and amylopectin content decreased significantly $(\mathrm{p}<0.05)$ during the 7 months of post-harvest conservation. Values ranged from $57.32 \pm 1.25$ to $37.39 \pm 0.81 \%$ and from $32.38 \pm 1.13$ to $21.12 \pm 0.74 \%$ respectively. This decrease in amylose and amylopectin levels may be attributed to the enzymatic hydrolysis of starch. Indeed, during post-harvest conservation, there is a proliferation of amylolytic enzymes such as $\alpha$ and $\beta$-amylases, $\alpha-1,4, \alpha-1,6$-glucosidases, and phosporylases. These enzymes catalyze the degradation of starch, releasing glucose, maltose and maltodextrins [17, 18, 19, and 20].

Table1. Chemical composition of Yam starch of Dioscorea alata cv "brazo" during post-harvest storage

\begin{tabular}{lccccc}
\hline $\begin{array}{l}\text { Storage time of } \\
\text { tubers (month) }\end{array}$ & \multicolumn{5}{c}{ Starch composition (\%) } \\
\cline { 2 - 5 } & Lipids & Proteins & Ash & Amylose & Amylopectin \\
\cline { 2 - 6 } $\mathbf{0}$ & $0.45 \pm 0.01^{\mathrm{a}}$ & $0.97 \pm 0.02^{\mathrm{a}}$ & $0.58 \pm 0.04^{\mathrm{a}}$ & $57.32 \pm 1.25^{\mathrm{a}}$ & $32.38 \pm 1.13^{\mathrm{a}}$ \\
$\mathbf{1}$ & $0.47 \pm 0.02^{\mathrm{a}}$ & $0.96 \pm 0.05^{\mathrm{a}}$ & $0.57 \pm 0.04^{\mathrm{a}}$ & $54.95 \pm 1.20^{\mathrm{b}}$ & $31.05 \pm 1.08^{\mathrm{b}}$ \\
$\mathbf{2}$ & $0.48 \pm 0.01^{\mathrm{a}}$ & $0.98 \pm 0.03^{\mathrm{a}}$ & $0.54 \pm 0.07^{\mathrm{a}}$ & $51.89 \pm 1.13^{\mathrm{c}}$ & $29.31 \pm 1.02^{\mathbf{c}}$ \\
$\mathbf{3}$ & $0.49 \pm 0.03^{\mathrm{a}}$ & $0.98 \pm 0.04^{\mathrm{a}}$ & $0.56 \pm 0.05^{\mathrm{a}}$ & $49.85 \pm 1.09^{\mathrm{d}}$ & $28.17 \pm 0.98^{\mathrm{d}}$ \\
$\mathbf{4}$ & $0.47 \pm 0.02^{\mathrm{a}}$ & $0.95 \pm 0.05^{\mathrm{a}}$ & $0.55 \pm 0.06^{\mathrm{a}}$ & $47.44 \pm 1.03^{\mathrm{e}}$ & $26.80 \pm 0.93^{\mathrm{e}}$ \\
$\mathbf{5}$ & $0.45 \pm 0.03^{\mathrm{a}}$ & $0.97 \pm 0.06^{\mathrm{a}}$ & $0.56 \pm 0.04^{\mathrm{a}}$ & $43.41 \pm 0.9^{\mathrm{f}}$ & $25.65 \pm 0.89^{\mathrm{f}}$ \\
$\mathbf{6}$ & $0.47 \pm 0.04^{\mathrm{a}}$ & $0.96 \pm 0.04^{\mathrm{a}}$ & $0.55 \pm 0.07^{\mathrm{a}}$ & $40.98 \pm 089^{\mathrm{g}}$ & $23.16 \pm 0.81^{\mathrm{g}}$ \\
$\mathbf{7}$ & $0.42 \pm 0.03^{\mathrm{a}}$ & $0.81 \pm 0.05^{\mathrm{a}}$ & $0.54 \pm 0.03^{\mathrm{a}}$ & $37.39 \pm 0.81^{\mathrm{h}}$ & $21.12 \pm 0.74^{\mathrm{h}}$ \\
\hline
\end{tabular}

Mean \pm standard deviation, $\mathrm{n}=3$ over which the means affected by a common letter are not significantly different $(\mathrm{p}=0.05)$.

\subsection{Swelling and Solubility}

Swelling capacity of different starch samples with the temperature is shown in Figure 1. The swelling pattern showed that at the temperatures lower than $75^{\circ} \mathrm{C}$, granules of starch samples resisted swelling, probably due to their high initial gelatinization temperature. From 75 to $95^{\circ} \mathrm{C}$, the granules gradually swelled as temperature increased. One of the most important structural characteristics of starch is that it passes through several different stages during gelatinization from water absorption to granule disintegration. When starch is heated in excess water, the semi-crystalline structure is lost and water molecules associate by hydrogen bonding to hydroxyl groups exposed on the amylose and amylopectin molecules. This association causes swelling and increases starch granules [21, 22]. Initially, starch granules swelling is reversible, increasing their volume up 30\% [23]. Water absorption and heating of the starch dispersion breaks the hydrogen bonds responsible for granule cohesion. Water penetrates the interior of the starch granules, hydrating linear fragment of amylopectin. This process leads to irreversible swelling, increasing the starch granules size several fold and the paste viscosity. This result agrees with the observations of others [24], which indicate that the swelling power of enset starch increased as temperature increased. No significant difference $(p<0.05)$ was observed between starch samples. At $95^{\circ} \mathrm{C}$, starches showed an average value of $12.44 \pm 0.43 \mathrm{~g}$ of water $/ \mathrm{g}$ of starch.

Solubility behaviour of starch samples at various temperatures $\left(50\right.$ to $\left.95^{\circ} \mathrm{C}\right)$ is shown in Figure 2 . From 50 to $75^{\circ} \mathrm{C}$, the solubility of starch granules increased slightly with values ranging from $1.9 \%$ to $4.2 \%$. On the other hand, from $75^{\circ} \mathrm{C}$ to $95^{\circ} \mathrm{C}$ a gradual increase in solubility was observed with values ranging between 17 and $19 \%$ at $95^{\circ} \mathrm{C}$. Like the swelling, the solubility of the starch granules during the hydrothermal treatment also did not vary significantly $(\mathrm{p}<0.05)$ during the 7 months of yam storage and followed the same trend as the swelling power. The solubility of Dioscorea alata L. cv "brazo" $(17-19 \%)$ at $95^{\circ} \mathrm{C}$ is close to that of starch of Dioscorea dumeterum (16.8\%) [25]. Solubility of starch is an indicator of the degree of starch granules dispersion after heating. It could refer to the amount of amylose leaching out from starch granule when swelling. Therefore, the higher the solubility, the higher will be the amylose leaching [26, 27]. 
International Journal of Advances in Scientific Research and Engineering (ijasre), Vol 5 (8), August-2019

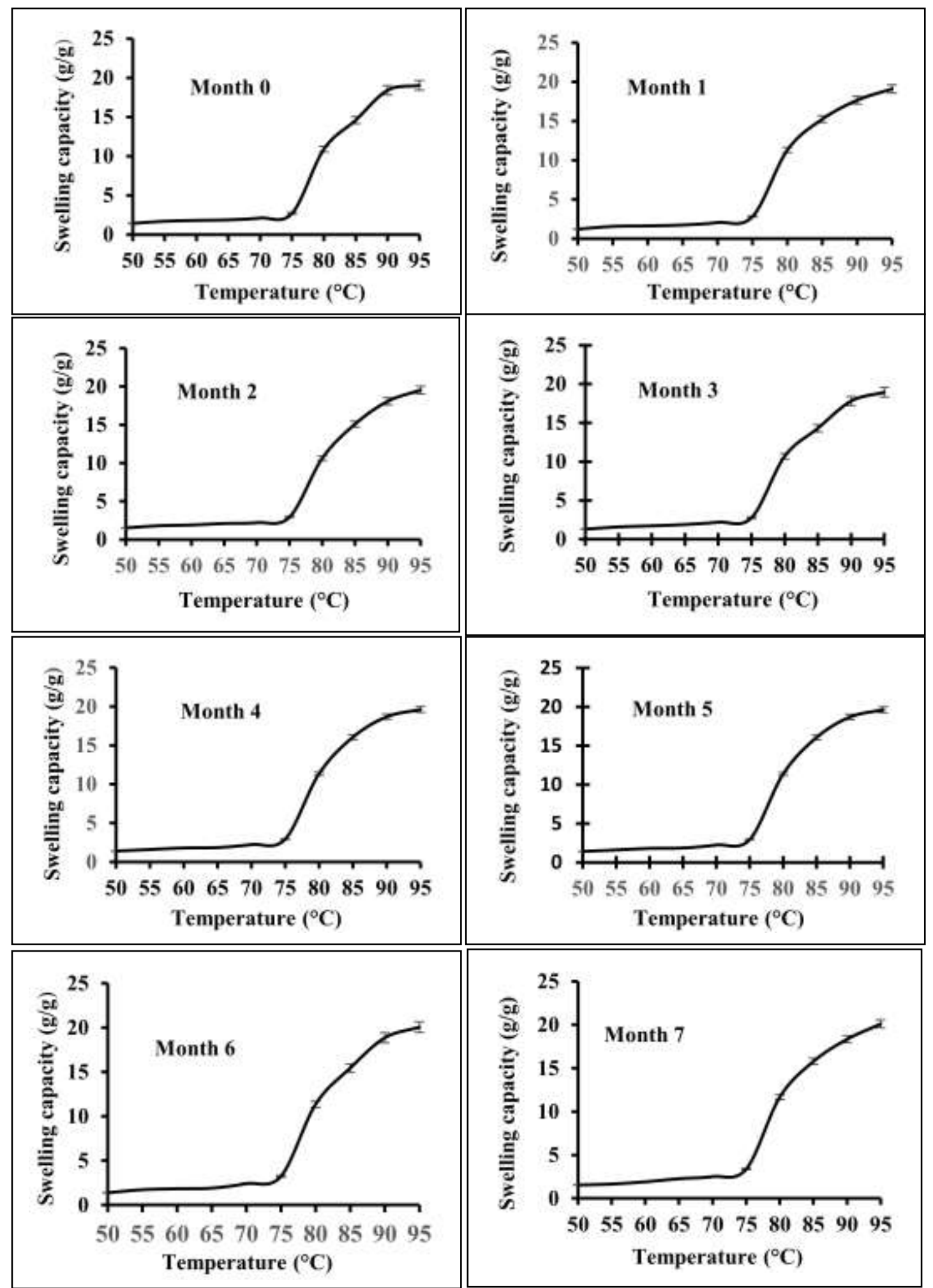

Figure 1. Swelling capacity of starch from yam tuber Dioscorea alata cv "Brazo" during the post-harvest storage time 


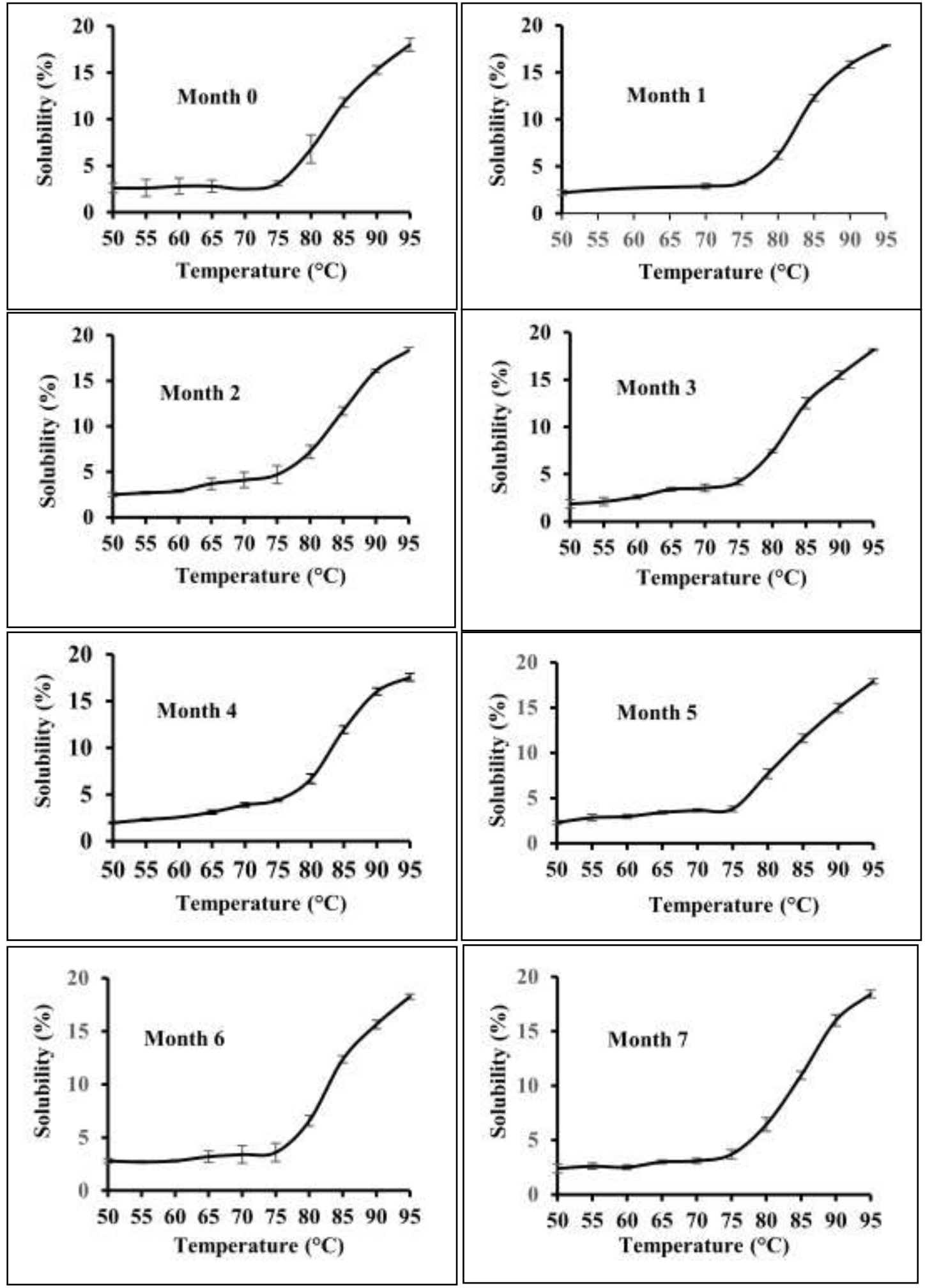

Figure 2. Solubility of starch from tuber of Dioscorea alata cv "Brazo" during the post-harvest storage time.

\subsection{Syneresis}

The determination of syneresis from refrigerated and frozen starch gels is often used to evaluate the ability of starch to resist the undesirable physical changes that occur during refrigeration and freezing. According to [28], the syneresis in a gel is caused by an increase in the molecular associations between starch chains, in particular the retrogradation of amylose which results in the expulsion of water from the structure of the gel [29]. Thus the amount of water released due to syneresis is a useful indicator of the tendency of starch to retrograde [30]. However, in starch gel containing ingredients which can bind to water molecules such as hydrocolloids or sugars, syneresis is reduced [31, 32, and 33]. The syneresis of starch gels from Dioscorea alata $\mathrm{L} . \mathrm{cv}$ "Brazo" at different periods of post-harvest storage during refrigeration $\left(4^{\circ} \mathrm{C}\right)$ and freezing $\left(-18^{\circ} \mathrm{C}\right)$ is presented in fig. 3 and 4 respectively. The post-harvest storage time had no influence on the syneresis of starch gels subjected to refrigeration $\left(4^{\circ} \mathrm{C}\right)$ and freezing $\left(-18^{\circ} \mathrm{C}\right)$. Syneresis of starch gels stored in the refrigerator $\left(4^{\circ} \mathrm{C}\right)$ did not vary significantly $(\mathrm{p}<0.05)$ during the 
International Journal of Advances in Scientific Research and Engineering (ijasre), Vol 5 (8), August-2019

first 14 days of storage. Stable values were obtained at an average of $5.81 \pm 0.83 \mathrm{~g}$ of water / $\mathrm{g}$ of starch. On the other hand, from the 14th day, an increase in syneresis reaching a value of $12.48 \pm 1.44 \mathrm{~g}$ of water $/ \mathrm{g}$ of starch was observed. The syneresis of starch gels stored in the freezer did not significantly change during 21 days $(\mathrm{p}<0.05)$. It remained stable with an average value of $5.30 \pm 0.65 \mathrm{~g}$ of water $/ \mathrm{g}$ of starch. From the $21 \mathrm{st}$ day, it increased significantly to reach on the 28 th day an average value of $11.22 \pm 0.98 \mathrm{~g}$ of water $/ \mathrm{g}$ of starch.

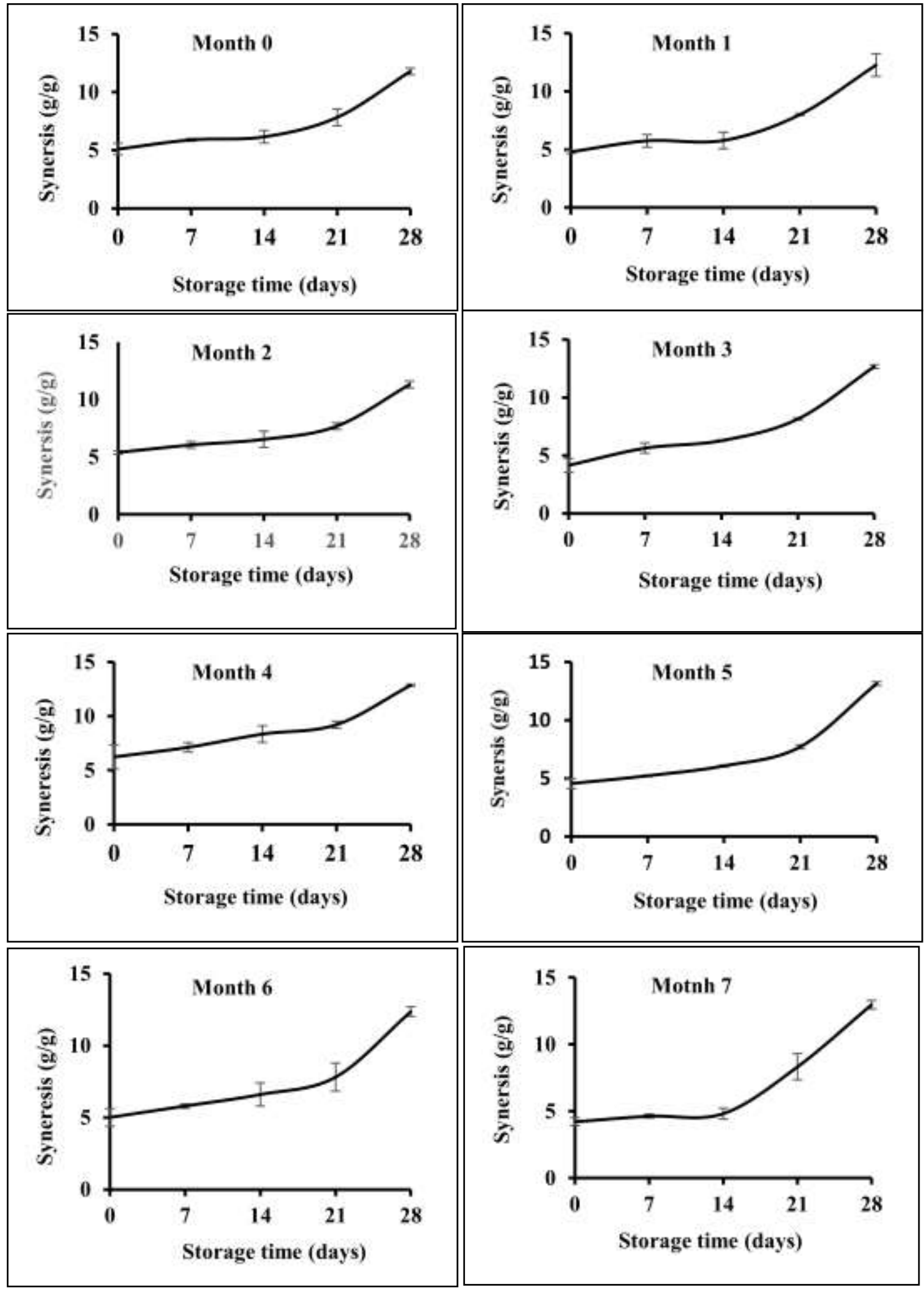

Figure 3. Syneresis of starch gels from tubers of Dioscorea alata cultivar "Brazo" during refrigeration $\left(4^{\circ} \mathrm{C}\right)$. 


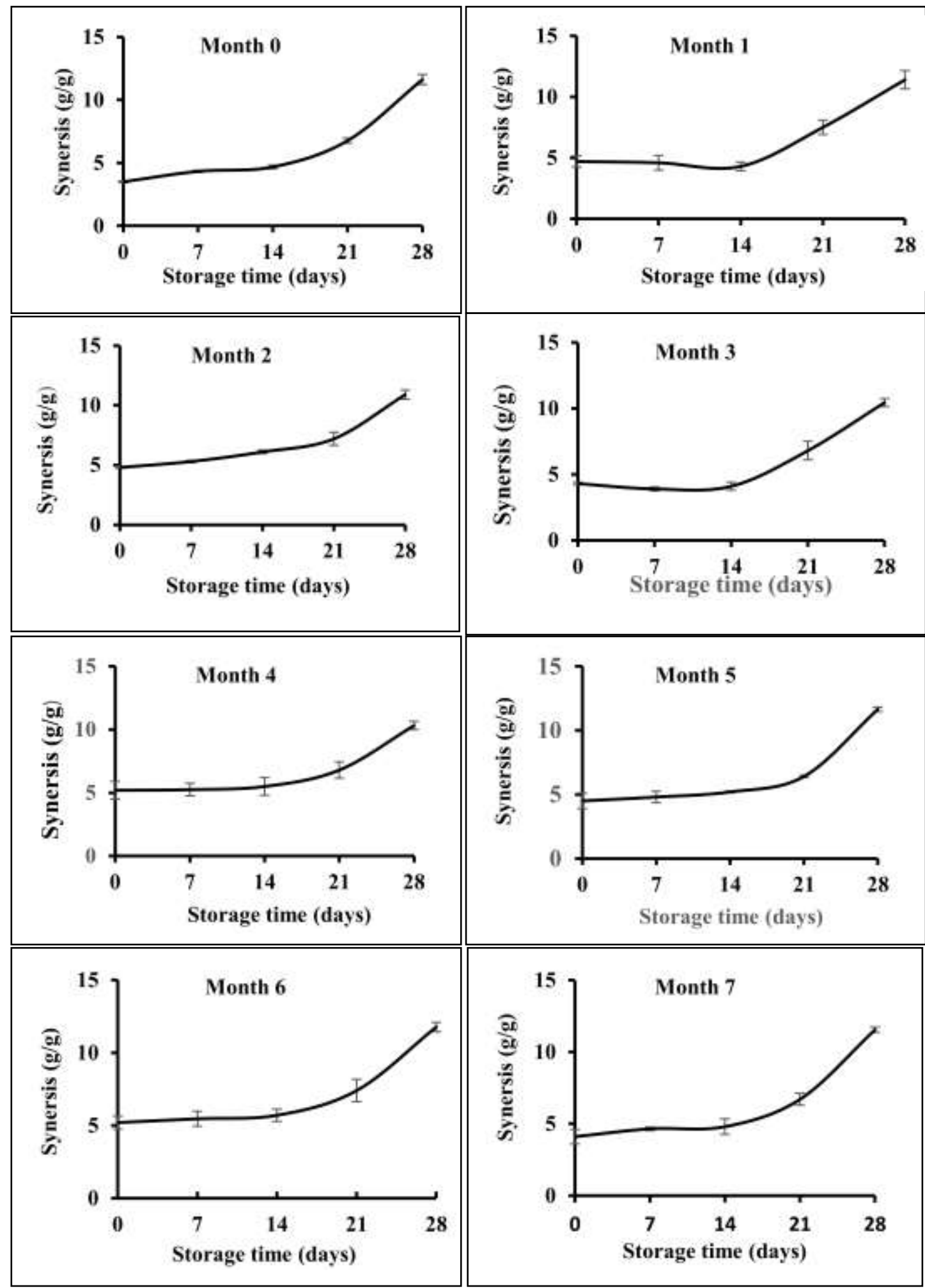

Fig. 4. Syneresis of starch gels from tubers of Dioscorea alata cultivar "Brazo" during freezing (-18 $\left.{ }^{\circ} \mathrm{C}\right)$.

\subsection{Pasting Properties}

Pasting behaviors of starch of Dioscorea alata cv "Brazo" at different periods of post-harvest storage as measured by brabender viscoamylograph are shown in figure 4. The corresponding values of the pasting characteristics are presented in table 2. According to the viscoamylogram patterns, no significant difference $(\mathrm{p}<0.05)$ was observed between the starches in their behavior during heating and cooling in excess water. Any distinct peak viscosity was not observed as it is generally seen with wheat and some other cereal, root and tuber starches [34]. But, these viscosity curves are similar to that obtained for starches of yams of some Dioscorea species [35, 25]. The starch samples showed an increase in viscosity as the temperature reached and was maintained at $95^{\circ} \mathrm{C}$ for $15 \mathrm{~min}$, suggesting the stability of the starches paste and the gradual crystalline disruption [36]. Indeed, 
when starch granules are heated with sufficient water, the starch suspension swells and the viscosity of the system increases. Starches showed a very low level of breakdown with negative values ranging between -170 and -95 . Starches increased in viscosity during cooling to $50^{\circ} \mathrm{C}$. They gave a higher setback which values ranged between 440 and 535 . This increasing of the viscosity of starch pastes during the cooling cycle is due to the phenomenon of retrogradation. Starch Retrogradation is a process which occurs when molecules comprising gelatinized starch begin to reassociate in an ordered structure. In its initial phase, two or more starch chains may form a simple juncture point which may then develop into more extensively ordered regions. Ultimately, under favorable conditions, a crystalline order appears [37]. Retrogadation is caused by the formation of hydrogen bonds between hydroxyl groups and by hydrophobic interactions formed, resulting in gel at lower temperature [38, 39]. All starch samples presented a higher final viscosity, showing a stability to stirring and cooking. The starch samples gave high pasting temperatures $\left(73-77^{\circ} \mathrm{C}\right)$. But these pasting temperatures were lower than that $\left(80-86^{\circ} \mathrm{C}\right)$ reported for Dioscorea alata $\mathrm{L}$ [40]. The pasting time (20 min) and cooking times (27-30 min) were higher

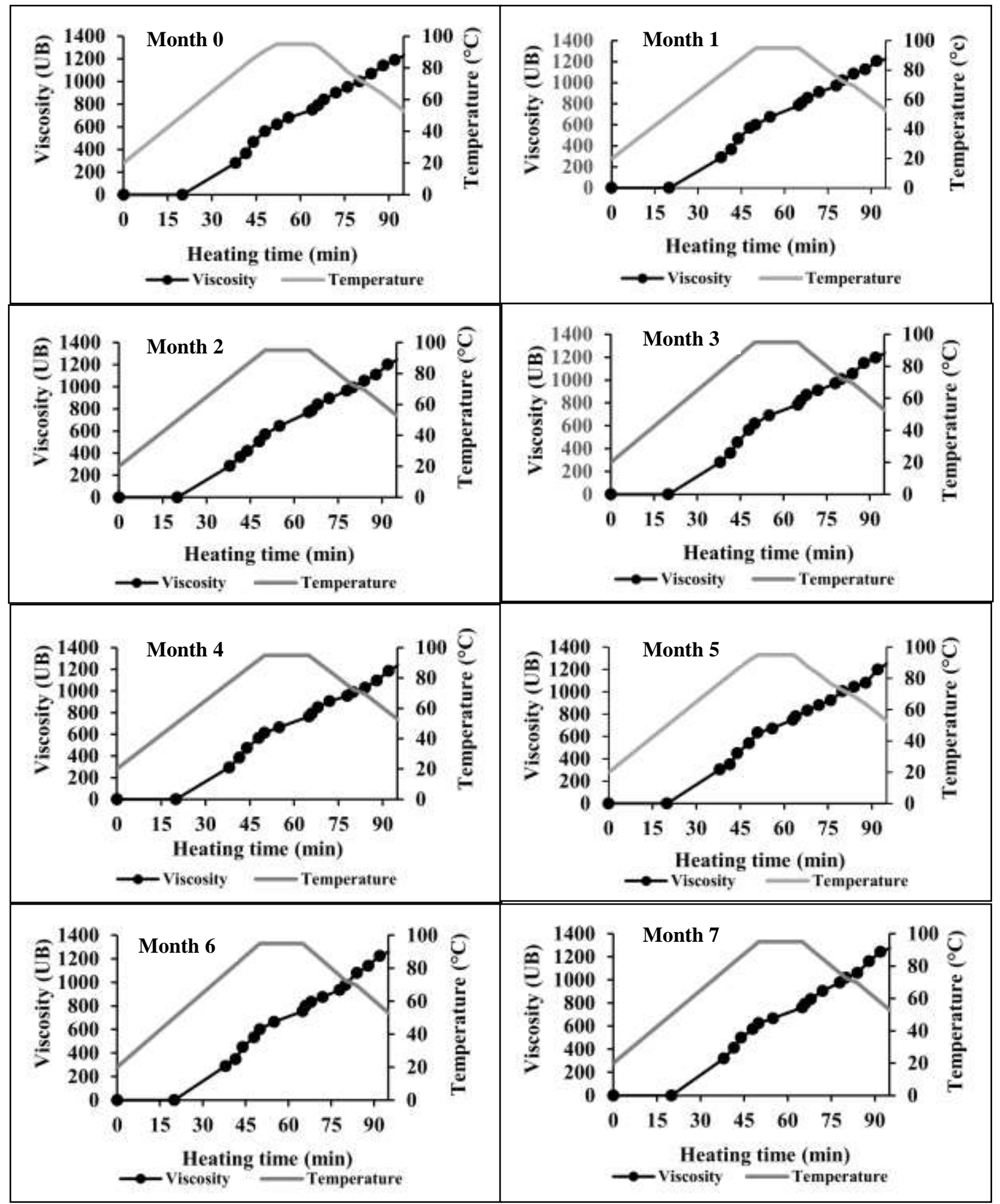

Figure 5. Viscosity of starch from yam tuber Dioscorea alata cv "Brazo" during the post-harvest storage time. 


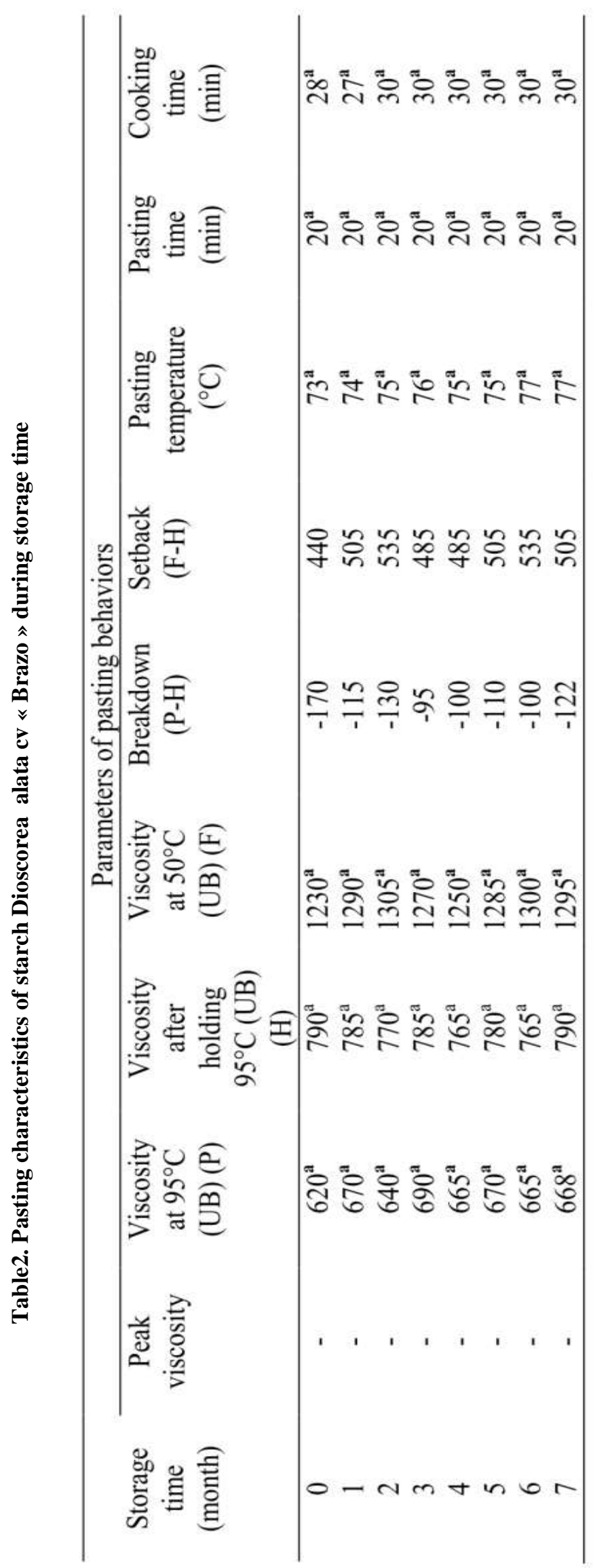




\section{CONCLUSION}

It appears from this study that the chemical properties of starch of Dioscorea alata L. cv "Brazo" such as proteins, lipids and ash content did not vary significantly during post-harvest storage, but amylose and amylopectin content did decrease. However, the functional properties remained unchanged. This suggests that the tubers of Dioscorea alata L. cv "brazo" would retain their techno-functional properties during post-harvest storage. During this study, we also noted that the viscoamylogram profile of starch pastes did not give a peak of viscosity but an increasing viscosity during heating and cooling cycle. The parameters of pasting behaviors did not varied during the storage time and starch pastes appeared to be thermo-stable. They showed a high setback after cooling, which resulted in a high retrogradation tendency. Starches also showed a high degree of swelling and solubility and less syneresis when subjected to refrigeration or freezing.

\section{REFERENCES}

1. .M.F.S. N'go Ngwe and D.N.S.J. Omokolo, "Evolution and phylogenetic diversity of yam species (Dioscorea spp.): implication for conservation and agricultural practices. PLOS ONE, 10 (12) 2015, https//doi.org/10.1371/journal.pone.0145364.

2. R.D. Salgado-Ordosgoitia, J.A. Rodríguez-Manrique, C.S. Cohen-Manrique and G.P. Mendoza-Ortega. Characterization of the techno-functional properties of starch from Purple yam (Dioscorea alata), Hawthorn yam (Dioscorea rotundata) and Diamante 22-type yam". DYNA, 85(207), 2018 pp. 143-152.

3. I.J. Odimegwu, O. Olukemi, Y.K. Ritesh, C.S Chanotiya, S. Ogbonnia and S.N. Sangwan. A new source of elemol rich essential oil and existence of multicellular oil glands in leaves of the Dioscorea species. The Scientific World Journal, 2013, pp. 1-6. http //dx.org/10.1155/2013/943595.

4. A. Dansi, H. Dantsey-Barry, I. Dossou-Aminon, E.K. N'Kpenu, A.P. Agré, Y.D. Sunu, K. Kombaté, Y.L. Loko, M. Dansi, P. Assogba and R. Vodouhe R. Varietal diversity and genetic erosion of cultivated yams (Dioscorea cayenensis Poir - D. rotundata Lam complex and D. alata L.) in Togo. International Journal Biodiversity and. Conservation, Vol. 5(4), 2013, pp. 223-239.

5. C. Ike and E.O. Inoni. Determinants of yam production and economic efficiency among small-holder farmer in southeastern Nigria. Journal of Central European Agriculture, vol.7, no 2, 2006, pp. 337-342.

6. A.M. Kouakou, G.P Zohouri, K.E. Dibi, B. N'Zué and K. Foua-Bi. Emergence d'une nouvelle variété d'igname de l'espèce Dioscorea alata L., la C18, en Côte d'Ivoire. Journal of Applied Biosciences, 57, 2012 pp.

7. K.E. Koffi, A.M. Kouakou, L. Samagaci, G.K. Brou, B. N'Zué, M.K Koussi and K.H. Kouamé. Genetic and enzymatic polymorphisms of interspecific Discorea praensilis-Discorea rotundata hybrides from Côte d'Ivoire. International Journal of Development Research, Vol. 5, Issue 06, 2015, pp. 4564-4569.

8. V. Chinelo and E.M. Okpara. Evaluation of the chemical, functional and pasting properties of starch from trifoliate yam (Dioscorea dumetorun) Landraces. European Journal of Advanced Research in Biological and Life Sciences, Vol.4 No. 2, 2016, pp. 53-62.

9. E.O. Afoakwa and S. Sefa-Dedeh. Chemical composition and quality changes in trifoliate yam Dioscorea dumetorum tubers after harvest. Journal of Food Chemistry, 75(1), 2001, pp. 85-91.

10. M.A. Libra, J.T Gonnety, A.P. Ahi, S. Dabonne, E.D. Ahipo and L.P. Kouame. Physicochemical changes in Bulbils of Two Cultivars of Dioscorea bulbifera During the Ripening Period. Advance Journal of Food Science and Technology 3(5), 2011, pp. 327-331.

11. L.M. Archange, D. Soumaila. B. Siaka, G.J. Tia, K. L. Patrice. Physicochemical properties and digestibility of starch from bulbils of two cultivars of Dioscorea bulbifera during the growth. International Journal of Agronomy and Agricultural Research Vol. 2, No. 12, 2012, pp. 34-42.

12. AOAC. Official Methods of Analysis $18^{\text {th }}$ edition". Association Official Analytical Chemists. Washington D.C. 2005

13. B.I.P.E.A. Recueil des méthodes d'analyse de la communauté Européenne. Bureau Interprofessionnel d'Etudes Analytiques, 1976, pp. 1-110.

14. P. Pingault. Caractérisation d'amidon de racines et de tubercules. Andins : étude de la synérèse et de la résistance à différentes contraintes. Mémoire de fin d'études. CIRAD/CIAT, Université de Technologie de Compiègne, Compiègne, France, pp.74. 1995.

15. P.A Elevina, S.S Forrest and P.D. Emperatríz. Characterization of some properties of starches isolated from Xanthosoma sagittifolium and Colocassia esculenta. Carbohydrate polymers, 69, 2005, pp. 139-145.

16. Oyeyinka, A.T. Oyeyanka, R.M. Kayyde, O.F. Olagunju, O.R. Karim and J.K Joseph. A review on the functionality and potential applications of bitter yam starch. Annals. Food Science and Technology, (8)3, 2017, pp. 364-375.

17. J.R.O.Do Nascimento, B.R. Cordenunsi, F.M Lajolo. Beta-amylase expression and starch degradation during banana ripening. Postharvest Biol. Technol., 40, 2006, pp.41-47.

18. A.O Adebiyi, A.P. Adebiyi and E.O. Olaniyi. Biological studies on albino rats fed with Sorghum bicolor starch hydrolyzed with a-amylase from Rhizopus sp. African Journal of Biotechnology, 4, 2005, pp. 1089-1094. 
19. T. Matsubara, Y. Ben Ammar, T. Anindyawati, S. Yamamoto, K. Ito, M. Iizuka and N. Minamiura. Degradtion of raw strach granules by $\alpha$-amylase purified from culture of Aspergillus awmori KT-11. Jounal of Biochemistry and Mololecular Biology, 37, 2004, pp. 422-442.

20. J.C. Valetudie, P. Colonna, B. Bouchet and D.J. Gallant. Hydrolysis of tropical tuber starches by bacterial and pancreatic $\alpha$-amylases. Starch/ Stärke, 45, 1993, pp. 270-276.

21. J.O. Arawande and A.O. Ashogbon. Isolation and characterization of starch obtained fromcocoyam cultivated at Akungba Akoko, Ondo State, Nigeria. Nutrition \& Food Science International Journal, (8) 2, 2019, pp.1-6.

22. N. Singh, J. Singh, L. Kaur, N.S. Sodhi and B.S. Gill. Morphological, thermal and rheological properties of starches from different botanical sources. Food Chemistry, 81(2), 2003, 219-231.

23. A. Gryszkin, T. Zieba, M. Kapelko and A. Buczek. Effect of thermal modifications of potato starch on its selected properties. Food Hydrocolloids, 40, 2014, pp. 122-127.

24. R.M. Gebre and P.C. Schmidt. Isolation and Physicochemical Properties of Enset Starch. Starch/Starke, Vol. 48, No. 6, 1996, pp. 208-214.

25. O.L. Emiola and L. Delarosa. Physicochemical characteristics of yam starches. Journal of Food Biochemistry 5, 1981, pp. 115-130.

26. S. Srichuwong, C. Suharti, T. Mishima, M. Isono, and M. Hisamatsu. Starches from different botanmical sources: Contribution of starch structure to swelling and pasting properties. Carbohydrate Polymers 62(1), 2005, pp. 25-34.

27. R. Hoover, T. Hughes, H. Chung and Q. Liu. Composition, molécular structure, properties and modification of pulse starches. A review. Food Research International, 43, 2010, pp. 399-413.

28. V.J. Morris. Starch gelation and retrogradation. Trends in Food Science and Technology, 1, 1990, pp. 2-6.

29. S. Saartratra, C. Puttanlekb, V. Rungsardthong and D. Uttapap. Paste and gel properties of low - substituted acetylated canna starches. Carbohydrate Polymers, 61, 2005, pp. 211-221.

30. A.A. Karim, M.H. Norziah and C.C Seow. (2000). Methods for the study of starch retrogradation. Food Chemistry, 71, 2000, pp. 9-36.

31. T. Arunyanart and S. Charoenrein. Effect of sucrose on the freeze-thaw stability of rice starch gels: Correlation with microstructure and freezable water. Carbohydrate Polymers, 74, 2008, pp. 514-518.

32. L.A. Baker and P. Rayas-Duarte (1998). Freeze-thaw stability of amaranth starch and the effects of salt and sugars. Cereal Chemistry, 75, 1998, pp. 301-307.

33. M. Yoshimura, T. Takaya and K. Nishinari. Rheological studies on mixtures of corn starch and konjac-glucomannan. Carbohydrate Polymers, 35,1-2, 1998, pp. 71-79

34. J. Brnnschweiler, D. Luethi, S. Handschin, Z. Farah, F. Escher and B. Conde-Petit. Isolation, physicochemical, characterization and application of yam (Dioscorea spp.) starch as thickening and gelling Agent. Starch/Stärke, 57, 2005, pp. 107117.

35. D. Polycarp, E.O. Afoakwa and A.K. Anane-Asamoah. Rheological properties of seven Different Yams (Dioscorea species) within the Yam Germplasm. Innovative space of Scientific Research Journals, 26, 2016, pp. 445-452.

36. C.C Huang, M.C. Lin and C.C. Wang. Changes in morphological, thermal and pasting properties of yams (Dioscorea alata) starch during growth. Carbohydrate Polymers, 64(4), 2006, pp. 524-531

37. W.A. Atwell, L.F. Hood, D.R. Lineback, E. Varriano-Marston and H.F. Zobel. Terminology and methodology Associated with basic starch phenomena. Cereal Food Word, 33, 1988, pp. 306-311

38. K. Leelavathi, D. Indrani and J.S. Sidhu. Amylograph pasting behaviours of cereal and tuber starches. Starch, 39 (11), 1987, pp. 378-381

39. R. Hoover and F.W. Sosulski. Composition, structure functionality and chemical modification of legume starches. $A$ review, Canadian Journal of Physiology and Pharmacology, 69, 1991, pp. 79-92.

40. M.O. Oke, S.O. Awonorin and T.S. Workneh. Effect of varieties on physicochemical and pasting characteristics of water yam flours and starches. African Journal of Biotechnology, vol. (12) 11, 2013, pp. 1250-1256. 